\title{
Historical Development of the Federalism System in Malaysia: Prior to Independence
}

\author{
Wan Kamal Mujani * \\ Department of Arabic Studies and Islamic Civilization, \\ Faculty of Islamic Studies \\ The National University of Malaysia \\ 43600 Bangi, Malaysia \\ inawan@ukm.edu.my
}

\author{
Wan Hamdi Wan Sulaiman \\ Department of Arabic Studies and Islamic Civilization, \\ Faculty of Islamic Studies \\ The National University of Malaysia \\ 43600 Bangi, Malaysia \\ whamdi88@gmail.com
}

\begin{abstract}
This article discusses the development of the federalism system in Malaysia prior to independence. During its administration in Malaya, the British introduced the residents system to facilitate administrative affairs there. Hence in 1895, the Treaty of Federation was made and the Federated Malay States was formed by the British. The introduction of this treaty marks the beginning of a new chapter in the development of the federalism system in Malaya. One of the objectives of this research is to investigate the development of the federalism system in Malaysia prior to independence. This entire research uses qualitative methods through literature review i.e. historical study and content analysis methods such as an in-depth review of the books in question. This research found that the federalism system in Malaysia was developed after the Treaty of Federation was introduced by the British.
\end{abstract}

Keywords-History, Federalism, Malaya, before independence

\section{INTRODUCTION}

The federalism system was introduced by the British before Independence to facilitate the administrative system and management of the economy. The historical development of the federal government system in Malaysia is closely related to the expansion of British influence in Malaya. Before the federalism system was introduced, Malaya previously adopted the residents system introduced by the British in 1874, initially in the states of Perak, Selangor, Negeri Sembilan and Pahang. However, this system led to many inconsistencies in terms of administration, causing the level of development among the states to become imbalanced. To overcome this system's weakness, the British implemented the Treaty of Federation (1895) on July 1, 1986, by uniting all the four states under one administration center known as the Federated Malay States.

\section{CONCEPT OF THE FEDERALISM SYSTEM}

The federalism concept has existed since the Greek golden age in the 13th century BCE when city-states around Greece collaborated to improve their common security in facing attacks from enemies. Afterwards, in the 16th century CE the federalism concept began to spread to Europe when Jean Bodin who was an influential French political thinker asserted that the best administrative system was the federalism system because it promoted the unity of small territories to become a strong country such as Malaysia, United States of America, India,
Australia etc. According to the book Comparing Federal Systems in the 1990s, Bodin states that even though this system requires city-states to hand over territorial sovereignty to the central government, this does not mean that the territories will lose their identities. Meanwhile, the book Decline of the Nation-State asserts that this type of administrative system became more influential when the United States of America, which became independent from British influence in 1776, chose this system to govern the vast country. This system was later followed by Canada (1867), Australia (1901), India (1950), and Nigeria (1960 CE) [1].

\section{THE FEDERALISM SYSTEM PRIOR TO INDEPENDENCE}

The history of the federalism concept in Malaya began in 1895. Nevertheless, the weakness of this system stirred opposition from the Malay community who felt that their position and interests were being threatened by the federalism system. Prior to the arrival of the British, administration of Malay states was under the system of absolute monarchy, where the king or sultan became the source of law and head of government in their respective states. Nevertheless, the arrival of the British in 1824 through the Anglo-Dutch Treaty changed the administration system of the Malay States. The British became interested to interfere with the administrative affairs in Malaya.

Before the federalism system was introduced, Malaya had previously accepted the residents system introduced by the British in 1874 through the Treaty of Pangkor, which was the first form of interference from the British government. Firstly in the states of Perak, Pahang (1888), Selangor (1895), and Negeri Sembilan (1895). According to the book Government Policies and Ethnic Relations in Asia and the Pacific, behind interference in the four states, the British had their own intentions of taking over the power of the Malay state rulers. Through the residents system, the four states were forced to accept a British Resident to advise the sultan in all matters except religious affairs and Malay traditions. During that time, the Malay sultans lost their authority as the absolute ruler of their respective states and were instead ruled under British jurisdiction. Under the residents system, the British failed to standardize policies and administration in the four states, causing the level of development to become imbalanced. On July 1, 1895, the Treaty of Federation was implemented by the 
British under the name of the Federated Malay States. With the introduction of this treaty, a new chapter began in the development of the federalism system in Malaya. The federalism concept introduced by the British was not done in its true sense. It did not include the distribution of power and functions between the federal and state government. Instead, many decisions were made by the Resident-General.

In 1909, the transition of power from the Malay sultans to the Federal Government began with the formation of the Unfederated Malay States. As a result of the Treaty of Bangkok in 1909 between the Siamese government and the British, the Unfederated Malay States, which consists of Perlis, Kedah, Kelantan, Terengganu, and Johore, were forced to accept a British adviser in their respective states. There were differences in terms of the administration between the Federated Malay States and the Unfederated Malay States. The administrative system in the Federated Malay States was similar to the unitary system because all administrative powers were held by the Resident-General. On the other hand, the system of government in the Unfederated Malay States was similar to the confederate system (a confederation, the power of member states was preserved whereas their sovereignty was untouched and still intact) given that the government power was still held by each sultan in their respective states. At that time, the Unfederated Malay States refused to join the Federated Malay States due to fear of losing authoritative powers [2].

In 1914, the British succeeded in expanding its influence across the entire Malaya. In addition, an attempt to standardize the administration between the Straits Settlements (Singapore, Malacca, and Penang), the Federated Malay States and the Unfederated Malay States was also made. However, efforts to combine the three state administrations went to no avail. In fact, the inconsistencies between these administrations continued until the outbreak of World War II. It caused the entire Malaya to fall easily into the hands of the Japanese i.e. in only 55 days. Upon realizing this weakness, the Colonial Office in London finally made a new constitution for Malaya known as the Malayan Union. As early as 1942, the British had established the Malayan Planning Unit (MPU) in the United Kingdom to prepare for the reconstruction of Malaya after World War II. The planning unit was led by Major General Ralph Hone. The book Changing Visions of East Asia 1943-93: Transformations and Continuities states that Ralph Hone was tasked with drafting a new form of administration for Malaya after the war ended. Finally, after all the discussions had taken place, a proposal to combine the Federated Malay States, the Unfederated Malay States, Penang and Malacca to become the Malayan Union was made, while Singapore was maintained as a separate colony.

The book Defence and Decolonisation in South-East Asia: Britain, Malaya and Singapore 1941-68 asserts that the Malayan Union's plan to maintain Singapore as a separate colony was due to concerns that the Malay opposition towards Singapore's entry will compromise the reception of the plan. There were traditional suspicions among Malayan traders that the Singaporean business sector will affect their interests. Besides that, the British were also worried that the introduction of a liberal citizenship policy will cause anxiety among Malay leaders because of the huge Chinese-Singaporean population.

The proposal for the Malayan Union plan was announced by Edward Gent, the Deputy Permanent Under Secretary for the Colonies, for the first time in the Parliament of United Kingdom in January 1944. Bornean territories such as Sabah, Sarawak and Brunei were also included in the original plan but their entry was later removed from the final proposal as Borneo was still under a state of instability. In the same year, the Colonial Office invited Sir Harold MacMichael (a British representative) to go to Malaya to gather the signatures from Malay state rulers. It took him only 22 days to gather the signatures of every Malayan ruler as a result of the threats from the British government by forcing the Malay sultans to accept their proposal. They did not allow enough time for the sultans to consult with their respective council. In fact, the sultans who refused to sign the treaty were threatened to be replaced by another sultan.

After receiving the treaties in 1946, the British introduced the Malayan Union to facilitate and standardize administration and to prepare the Malayan people towards self-government. However, the Malayan Union faced stiff opposition from the Malay community at that time. The book Federalism in Asia: India, Pakistan and Malaysia provides details regarding the Malayan Union constitution which consist of nine Malay states, Malacca, and Penang united as one British colony lead by the British Governor. Singapore was not included because the British considered Singapore its sole property obtained through a treaty with Sultan Hussin. All jurisdictions of the Malay sultans in the Malayan Union government including rights to make foreign affair policies were taken over by the governor. The Malay sultans, even though they were given rights towards religion and Malay traditions, did not have authority over them because Their Highnesses were only ranked ordinary members in the council meetings chaired by the Malayan Union governor. The Malayan Union constitution also acknowledges the citizen status of immigrants through 'Jus Soli' at birth and leeway was given to immigrants who apply to become a Malayan Union citizen. As a consequence of the resistance by the Malay community towards the establishment of Malayan Union, the Malay community formed the United Malays National Congress (UMNO) which was held in Kuala Lumpur. Approximately 200 people representing Malays from 41 associations attended to discuss the formation of the National Malay Movement, as well as a campaign to demand that the Malayan Union be abolished. UMNO's formation aims to execute all initiatives and efforts to establish an independent and sovereign country. Its cause was to develop and safeguard the Malays interests in particular and the general population in all fields. UMNO also emphasizes the religion Islam and Malay traditions and strive to develop them. UMNO will protect the sovereignty of Malay sultans as a constitutional monarchy and will control and preserve the foundations of a parliamentary democratic government [3].

Even though the Malay community's opposition was tremendous, the British government refused to withdraw the execution of the Malayan Union plan. Instead, the British government insisted that the Malayan Union must be continued. However, the opposition towards Malayan Union was so strong 
that the plan was not able to be carried out completely. This can be seen when the inauguration of Edward Gent as the first Malayan Union governor was boycotted by the Malay sultans. Besides that, the Malay community also protested to stop the implementation of Malayan Union. They sent their representative, Dato' Onn Jaafar, to consult with the sultans to thwart the ceremony.

As a consequence of the strong opposition from the Malay community, the British were forced to abolish the Malayan Union and as a result of the negotiations of the workforce committee which consists of government representatives, sultans, and UMNO, a new constitution was successfully formed called the Federation of Malaya in 1948. Hence, the characteristics of a federalism system began to permeate into the Malayan administration system. The Federation of Malaya is made up of a federal government and 11 government members including nine Malay states and two Straits Settlements (Malacca and Penang). Besides that, a written constitution was also introduced in all states in Malaya except in Johore and Terengganu. The Malay sultans ruled according to their respective state constitutions as laid out in the Treaty of Federation.

In 1955, the first general election was held in Malaya to prepare the people towards self-government. In the election, support towards the Alliance Party (a coalition of United Malays National Organization (UMNO), Malaysian Chinese Association (MCA) and Malaysian Indian Congress (MIC)) was so overwhelming that it won 51 out of the 52 seats contested. Through this victory, Tunku Abdul Rahman as the President of the Alliance Party was then appointed as the Prime Minister of Malaya. In 1956, Tunku Abdul Rahman led a delegation to London to negotiate with the British with regards to the independence of Malaya. The negotiation led to the formation of the Reid Commission which was tasked to draft a constitution for the independence of Malaya [4].

\section{SUMMARY}

The Federalism System was introduced before independence by the British to facilitate administrative affairs and management of the economy in Malaya at that time. However, the federalism system implemented by the British was for their interests only. Hence in 1895, the Treaty of Federation was constructed by the British under the name of the Federated Malay States and through this treaty the federalism system was developed. After Independence, the federalism system was sealed in the Federal Constitution.

\section{ACKNOWLEDGMENT}

This Research was financially supported by the Arus Perdana Grant - 50 Year Federal Malaya: Achievements, Challenges and The Future (AP-2014-006), The National University of Malaysia.

\section{REFERENCES}

[1] R. L. Watts, Comparing Federal System in the 1990s, Kingston: Queen's Mc Gill University Press, 1996.

[2] V. Verma, Malaysia, State and Civil Society in Transition, Colorado: Lynne Rienner Publisher Inc, 2002.

[3] H. Bhattacharyya, Federalism in Asia India, Pakistan and Malaysia, New York: Routledge, 2010.

[4] Raja Nur Alaini Raja Omar, A historical perspective of federalism in Malaysia and its effects on the current system of federalism, International Journal of Business, Economics and Law, Vol. 1, 2012, pp. 125-129. 